\title{
FIELD EVALUATION OF SOME INSECTICIDES AGAINST THE \\ OLIVE PSYLLID, EUPHYLLURA STRAMINEA LOginOVa \\ (HOMOPTERA: PSYLLOIDEA, APHALARIDAE) ON OLIVE TREES IN ISMAILIA GOVERNORATE, EGYPT
}

\author{
YOUSSEF, A. S. ${ }^{1}$, A.H. AMIN ${ }^{2}$, E. A. EL-WAN ${ }^{1}$ AND A. HELMI ${ }^{2}$ \\ 1. Plant Protection Research Institute, ARC, Dokki, Giza \\ 2. Plant Protection Department, Faculty of Agriculture, Ain Shams University
}

(Manuscript received 25 August, 2010)

\begin{abstract}
A field experiment was carried out during April, 2010 in olive orchard cultivated in Sarapium, Ismailia Governorate to evaluate the efficiency of six insecticides against the olive psyllid, Euphyllura straminea Loginova (Homoptera : Psylloidea, Aphalaridae) on olive trees. The obtained results showed that, the tested insecticides were highly effective against the olive psyllid, E. straminea and protect the new emergency flowers from insect damages. The highest effective compounds on the nymphal population were Fenitrothion and Phosmet (98.25 - 98.50\%) followed by Imidacloprid (98.17\%) and Pyriproxyfen (97.82\%) whereas Chlorpyrifos and miscible mineral oil were the least effective (94.68 - 94.74\%), respectively. Also, Fenitrothion and Phosmet were the highest effective insecticides on the adult population showing 98.11 - 98.32\% followed by Pyriproxyfen and Chlorpyrifos (97.31 $97.58 \%)$. Imidacloprid (96.35\%) and Mineral oil came in last order (94.35\%).

The percentages of reduction in the insect population reached its maximum by the $4^{\text {th }}$ week, it reached more than $97 \%$ for the nymph and adult populations. The obtained results revealed that, the post-spraying counts must be continue 4 weeks after application to determine the efficiency of the evaluated insecticides for control the olive psyllid E. straminea on olive trees.
\end{abstract}

\section{INTRODUCTION}

The olive psyllid, Euphyllura straminea Loginova was recorded in Egypt for the first time on the olive trees in March, 1988 at Rafah, El-Arish (Nada, 1994). This species causes serious damage for the olive trees and reduce the olive production. Both nymphs and adults suck the plant sap from the leaves and flower buds and secreted a large amount of honeydew which encouraged the growth of sooty mould fungs. In addition the infested trees became dirty black appearance which affected on photosynthesis and respiration processes. During the last few years this species became a key pest in the cultivated olive orchards in many governorates in Egypt.

Field observations and ecological studies showed that the females of this species begin to be active from late March until late April. Adult females begin to deposit eggs in the terminal buds of old branches during this period. The females 
preferred flower clusters for laying eggs, especially between calyx and corolla. The severe infestation of the olive psyllid, E. straminea affected greatly on the olive yield, it causes falling of racemes or declines the number of floral buds/raceme and reduce the flower fertility which caused by drying the pistils.

Reviewing the available of literature showed few control measures for the olive psyllid, E. straminea in Egypt. Radwan (1996) stated that Fenitrothion 50\% EC at rate $0.3 \%$ gave $98.43 \%$ reduction for the olive psyllid population on olive trees in Fayoum Governorate.

The present work was conducted to evaluate the efficiency of six insecticides against the olive psyllid, E. straminea on olive trees under field conditions to minimize the losses of the olive yield from insect damages.

\section{MATERIALs AND METHODS}

The present work was conducted during April, 2010 in olive orchard (Tophahy cultivar) cultivated in Sarapium, Ismailia Governorate. The olive orchard about seven feddans and about 20 years old. Sixty three trees of same size, height and level of infestation were selected for experimental purposes. The experimental design was Randomized Complete Block (RCB). The selected trees were distributed in three blocks, each block ( 21 trees) was divided into 7 plots ( 3 trees /plot).

The experimental insecticides were randomly distributed in each block and replicated three times in the three blocks, while the seventh plot in the three blocks was left as control index. The tested compounds with their commercial and common names as well as rate of application are given in Table (1).

Spray application was conducted on 7, April, 2010 by using motor sprayer (1.5 hp) and 150 liters tank with pressure of 100 pound on square inch. The spraying was applied manually to secure complete coverage for all parts of olive trees.

The pre-spraying samples were picked up at random from each replicate before spraying application with rate of 10 twigs (20 cm long) / sample whereas the post-spraying samples were taken after one, two, three and four weeks intervals. The collected samples were kept in special plastic boxes and transferred to laboratory for counting procedures by aid of stereoscopic microscope. The insect population was sorted to dead and alive nymphs and adults and the reduction percentages were calculated according to Henderson and Tilton equation (1955). The statistical analysis was conducted by computer using MSTATC program. To separate between the means, the percentages of mortality were transferred to arc-sine, when "F" value was significant LSD values were determined. 
Table 1 . The evaluated insecticides with their formulations, common names and rates of application.

\begin{tabular}{|l|l|l|l|}
\hline Common name & Formulation - \% a. i & Pesticide group & \multicolumn{1}{c|}{ Rate of application } \\
\hline 1- Pyriproxyfen & Admiral 10\% E.C & $\begin{array}{l}\text { Juvenile Hormone mimic } \\
(\mathrm{JHm})\end{array}$ & $50 \mathrm{ml} / 100$ liter of water \\
\hline 2- Imidacloprid & Chinook 35\% SC & Neonicotinoid & $75 \mathrm{ml} / 100$ liter of water \\
\hline 3- Phosmet & Imidan 50\% W.P & Organphosphorous & $100 \mathrm{~g} / 100$ liter of water \\
\hline 4- Chlorpyrifos & Robust 48\% E.C & Organphosphorous & $125 \mathrm{ml} / 100$ liter of water \\
\hline 5- Fenitrothion & Sumithion 50\% E.C & Organphosphorous & $300 \mathrm{ml} / 100$ liter of water \\
\hline 6- Mineral oil & Super Royal 95\% E.C & Mineral oil & 1.5 liter/100 liter of water \\
\hline
\end{tabular}

\section{RESULTS AND DISCUSSION}

Data in Table (2) showed the pre- and post-spraying counts of $E$. straminea as well as the evaluated insecticides with their reduction percentages on nymph and adult populations after $1^{\text {st }}, 2^{\text {nd }}, 3^{\text {rd }}$ and $4^{\text {th }}$ week, respectively.

The obtained results revealed that the reduction percentages of the tested insecticides on the nymphal population were varied after one week of application. The highest effective compounds were Fenitrothion (96.9\%), Pyriproxyfen (96.2\%), Imidacloprid (96.2\%) and Phosmet (95.1\%) whereas the least effective compounds were Mineral oil (88.7\%) and Chlorpyrifos (86.9\%) respectively.

On the other hand, the evaluated insecticides showed the same trend on the adult population. The highest effective compounds after one week of application were Fenitrothion (96.9\%) followed by Pyriproxyfen (95.6\%) and Phosmet (95.3\%) while the lowest compounds were Chlorpyrifos (92\%), Imidacloprid (90.4\%) and Mineral oil $(89.2 \%)$, respectively.

Statistical analyses showed that, the tested insecticides were highly significant effect on reduction percentages of the nymphal population ( $F$ value $=1084.6$ ). The highest effective compounds were Fenitrothion and Phosmet they came in the $1^{\text {st }}$ rank (98.25 - 98.50\%) followed by Imidacloprid in the $2^{\text {nd }}$ rank $(98.17 \%)$. Pyriproxyfen came in the $3^{\text {rd }}$ rank $(97.82 \%)$ whereas Chlorpyrifos and Mineral oil came in the last rank $(94.68-94.74 \%)$, respectively.

Also, results of statistical analyses showed highly significant effect on the adult population $(F$ value $=8.8)$. The highest effective insecticides were Fenitrothion and Phosmet they came in the $1^{\text {st }}$ rank $(98.11-98.32 \%)$. Pyriproxyfen and Imidacloprid came in intermediate effectiveness $(97.31-97.58 \%)$ followed by Imidacloprid in the $3^{\text {rd }}$ rank (96.35\%) and Mineral oil came in the last one (94.35\%). 
Data in Table (2) and Figs. (1\&2) showed that, reduction percentages in the nymph and adult populations were varied in the 4 week of inspection, it increased gradually and reached more than $97 \%$ in the $4^{\text {th }}$ week of application.

The afore-mentioned results showed that, the tested insecticides were highly effective on the insect population and the real effect appeared after 4 weeks of application. So, the present work proved that, the tested compounds were more sufficient as control measure for the olive psyllid, E. straminea under field conditions.

Reviewing the available literature showed that, Fenitrothion $50 \%$ at rate of $0.25 \%$ gave $95.6 \%$ reduction for Icerya seychellarum (Westwood) on Cycas revolute at Zohria Botanic Garden, Giza governorate (El-Borollosy et al., 1990). Radwan (1996) stated that Fenitrothion $50 \%$ at rate of $0.3 \%$ was strongly efficient against $E$. straminea on olive trees it reduces the insect population to $98.43 \%$ in Fayoum governorate. Elwan et al. (2005) revealed that, Fenitrothion $50 \%$ EC at rate of $0.15 \%$ reduced the population of $P$. tenuivalvata in sugarcane fields to $98.1 \%$ in NagaHammadi, Qena governorate.

On the other hand, Pyriproxyfen $10 \%$ EC at rate of $0.05 \%$ gave $96.1 \%$ reduction for Parlatoria oleae on olive trees in Ismailia governorate (El-Amir, 2002) and $94 \%$ reduction for Hemiberlesia lataniae infesting guava trees in Giza governorate (Hassan , 2003). 
Table 2. Field evaluation of some insecticides against the olive psyllid, E. straminea infesting olive trees at Sarapium, Ismailia Governorate during April, 2010 with statistical analysis.

\begin{tabular}{|c|c|c|c|c|c|c|c|c|c|c|c|c|}
\hline \multirow{4}{*}{ Insecticide } & \multirow{2}{*}{\multicolumn{2}{|c|}{$\begin{array}{c}\text { Pre-spraying } \\
\text { counts }\end{array}$}} & \multicolumn{8}{|c|}{ Post- spraying counts and $\%$ of reduction } & \multirow{2}{*}{\multicolumn{2}{|c|}{$\begin{array}{c}\text { Average percent } \\
\text { of reduction } \\
\end{array}$}} \\
\hline & & & \multirow{2}{*}{\multicolumn{2}{|c|}{$\begin{array}{l}\text { One week } \\
14 / 4 / 2010\end{array}$}} & \multirow{2}{*}{\multicolumn{2}{|c|}{$\begin{array}{c}2 \text { weeks } \\
22 / 4 / 2010 \\
\end{array}$}} & \multirow{2}{*}{\multicolumn{2}{|c|}{$\begin{array}{c}3 \text { weeks } \\
30 / 4 / 2010 \\
\end{array}$}} & \multirow{2}{*}{\multicolumn{2}{|c|}{4 weeks }} & & \\
\hline & $7 / 4$ & 10 & & & & & & & & & & \\
\hline & Nymph & Adult & Nymph & Adult & Nymph & Adult & Nymph & Adult & Nymph & Adult & Nymph & Adult \\
\hline \multirow{2}{*}{ 1- Pyriproxyfen } & 297 & 89 & 14.33 & 5.0 & 13.0 & 5.0 & 8.0 & 3.0 & 6.67 & 2.0 & 10.50 & 3.75 \\
\hline & \multicolumn{2}{|c|}{$\%$ of reduction } & $96.2 \%$ & $95.6 \%$ & $97.6 \%$ & $97.2 \%$ & $98.6 \%$ & $98.5 \%$ & $98.9 \%$ & $98.9 \%$ & $97.82 \% \quad \mathbf{c}$ & $97.58 \% \mathbf{a b}$ \\
\hline \multirow{2}{*}{ 2- Imidacloprid } & 372 & 114 & 18.0 & 14.0 & 13.0 & 7.0 & 8.0 & 3.0 & 3.67 & 2.0 & 10.67 & 6.50 \\
\hline & \multicolumn{2}{|c|}{$\%$ of reduction } & $96.2 \%$ & $90.4 \%$ & $98.1 \%$ & $96.9 \%$ & $98.9 \%$ & $98.9 \%$ & $99.5 \%$ & $99.2 \%$ & $98.17 \%$ b & $96.35 \%$ b \\
\hline \multirow{2}{*}{ 3- Phosmet } & 419 & 116 & 26.0 & 7.0 & 8.0 & 4.0 & 7.33 & 2.0 & 1.33 & 1.0 & 10.67 & 3.50 \\
\hline & \multicolumn{2}{|c|}{$\%$ of reduction } & $95.1 \%$ & $95.3 \%$ & $98.9 \%$ & $98.3 \%$ & $99.1 \%$ & $99.3 \%$ & $99.8 \%$ & $99.6 \%$ & $98.25 \% \quad$ a & $98.11 \%$ a \\
\hline \multirow{2}{*}{ 4- Chlorpyrifos } & 243 & 127 & 40.67 & 13.00 & 25.0 & 4.33 & 8.33 & 3.0 & 3.33 & 0.0 & 19.33 & 5.08 \\
\hline & \multicolumn{2}{|c|}{$\%$ of reduction } & $86.9 \%$ & $92.0 \%$ & $94.3 \%$ & $98.3 \%$ & $98.2 \%$ & $99.0 \%$ & $99.3 \%$ & $100 \%$ & $94.68 \% \quad$ d & $97.31 \%$ ab \\
\hline \multirow{2}{*}{ 5- Fenitrothion } & 315 & 110 & 12.33 & 4.33 & 9.0 & 3.0 & 5.0 & 3.33 & 3.33 & 2.33 & 7.42 & 3.25 \\
\hline & \multicolumn{2}{|c|}{$\%$ of reduction } & $96.9 \%$ & $96.9 \%$ & $98.4 \%$ & $98.6 \%$ & $99.2 \%$ & $98.7 \%$ & $99.5 \%$ & $99.1 \%$ & $98.50 \%$ a & $98.32 \%$ a \\
\hline \multirow{2}{*}{ 6-Mineral oil } & 277 & 104 & 40.00 & 14.33 & 23.00 & 11.33 & 16.0 & 8.0 & 12.0 & 7.0 & 22.75 & 10.17 \\
\hline & \multicolumn{2}{|c|}{$\%$ of reduction } & $88.7 \%$ & $89.2 \%$ & $95.4 \%$ & $94.6 \%$ & $96.9 \%$ & $96.7 \%$ & $97.9 \%$ & $97.0 \%$ & $94.74 \%$ d & $94.35 \% \quad$ c \\
\hline Control & 323 & 119 & 412 & 152 & 582 & 238 & 610.67 & 273.67 & 681.00 & 267.00 & 571.42 & 232.67 \\
\hline \multicolumn{11}{|c|}{ F value between treatments: } & $1084.6^{* *}$ & $8.8^{* *}$ \\
\hline \multicolumn{11}{|c|}{ LSD at 0.05 level : } & 0.16 & 1.4 \\
\hline
\end{tabular}

Note:

Percent of reduction were transferred to arc sine values before conducting analysis of variance.

Means in the same column not followed by the same letter is significantly different $(P<0.05)$ using LSD test in MSTATC computer Program. 


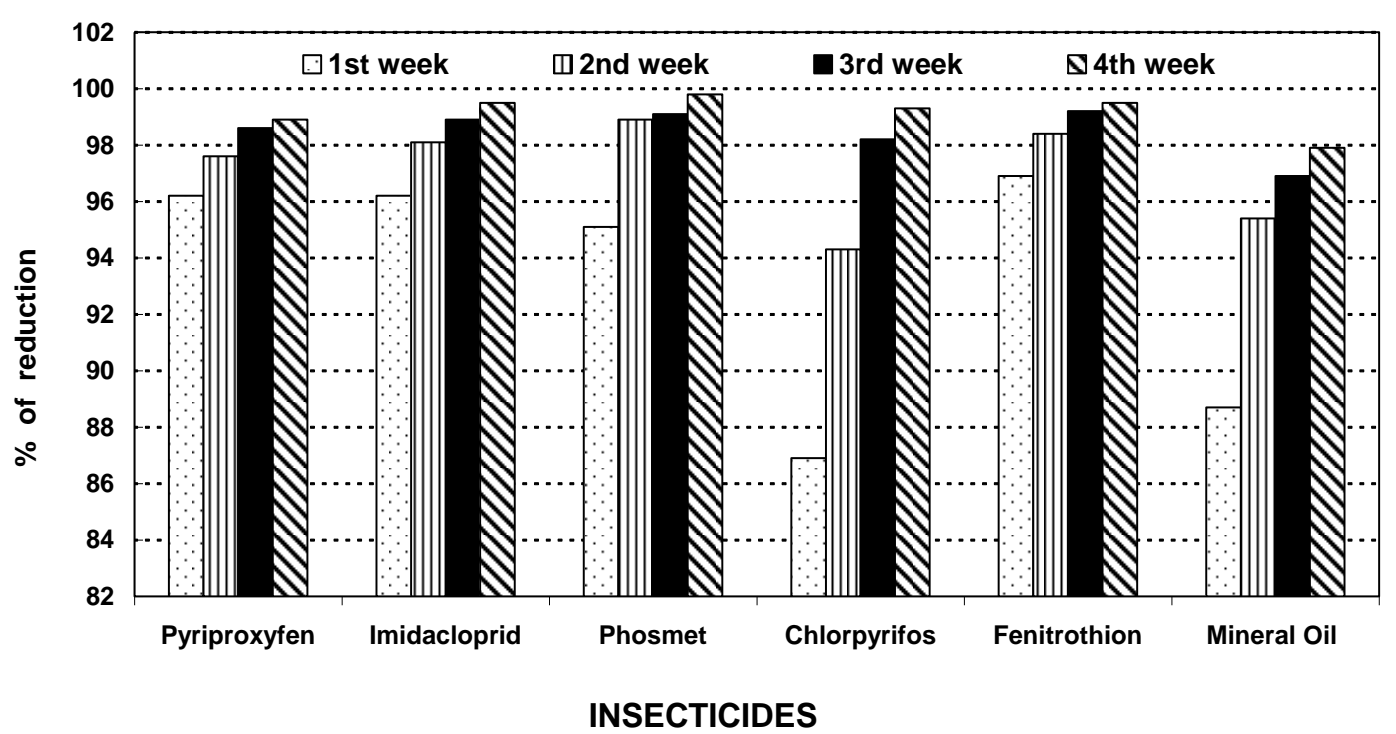

Fig. 1. Reduction percentages in the nymphal population of the olive psyllid, $E$. straminea after spraying with six insecticides at Sarapium, Ismailia Governorate during April, 2010.

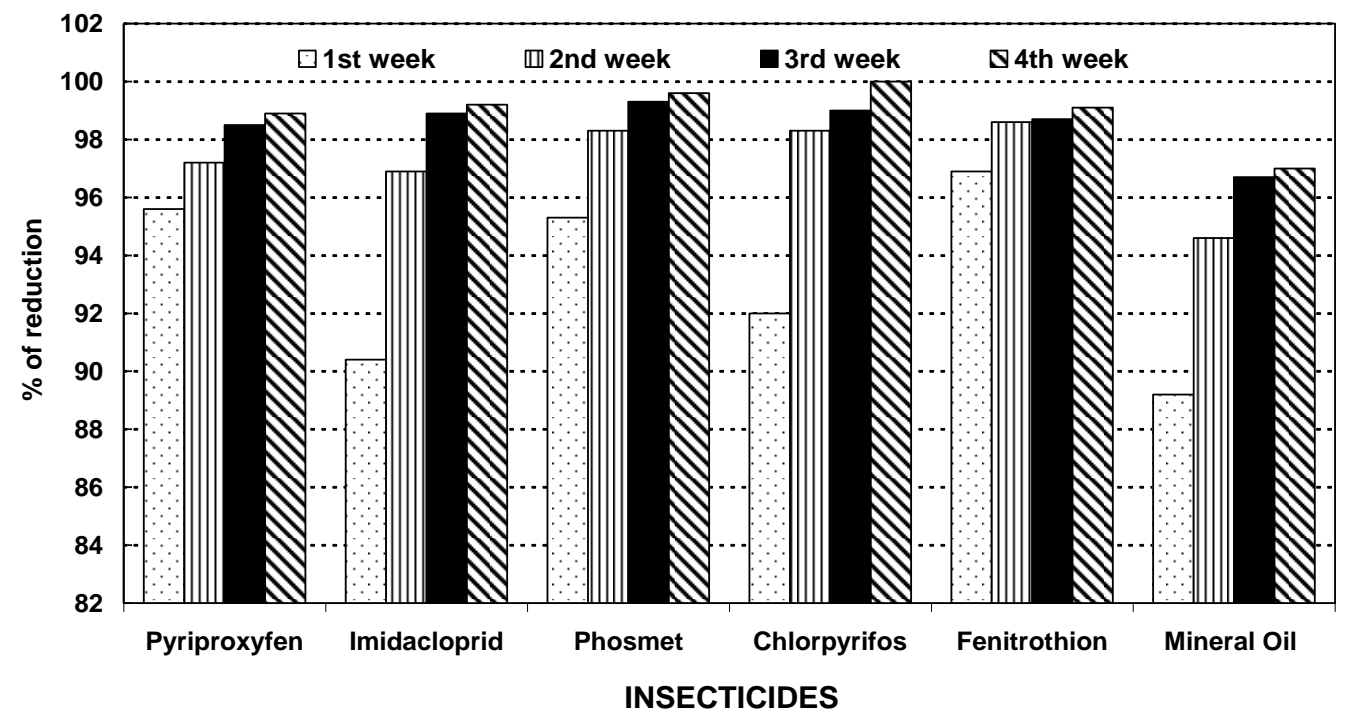

Fig. 2. Reduction percentages in the adult population of the olive psyllid, E. straminea after spraying with six insecticides at Sarapium, Ismailia Governorate during April, 2010. 


\section{REFERENCES}

1. El-Amir, S. E. 2002. Environmentally safe approaches for controlling some scale insects infesting olive trees in new reclaimed areas. M. Sc. Thesis Institute of Environmental Studies \& Research, Ain Shams Univ. pp.84.

2. El-Borollosy, F. M., M. M. El-Bolok, A. I. Ezz and S. M. Assem. 1990. Efficiency of certain insecticides and insect growth regulators (IGR's) in controlling three homopterous insects on ornamental plants. Bull. Ent. Soc. Egypt. Econ. Ser., 18: 185-194.

3. Elwan, E. A., M. S. I. Shalaby and M. M. Khewa. 2005. Efficiency of some insecticides for control Pulvinaria tenuivalvata (Newstead) (Homoptera: Coccidae) on sugarcane in Naga-Hammadi district, Qena governorate. Egypt. J. Agric. Res. 83 (4), 1649-1661.

4. Hassan, O.A. 2003. Ecological safe ways for controlling some insect pests attacking the guava trees at Giza governorate. M. Sc Thesis Institute of Environmental Studies \& Research, Ain Shams Univ. pp.149.

5. Henderson, C. F. and E. W. Tilton. 1955. Test with acaricides against the brown wheat mite, J. Econ. Entomol., 48: 157-161.

6. Nada, M. S.1994. Olive psyllid Euphyllura straminea Loginova on olive, pest new to Egypt (Homoptera: Psyllidae). Egypt. J. Agric. Res., (72):129-131.

7. Radwan, S. A. 1996. Toxicological and ecological studies on the olive tree Psylla Euphyllura straminea Loginova (Homoptera: Psylloidea). M. Sc Thesis, Fac. Agric. Cairo Univ., Egypt, 184 pp. 
التقييم الحقلى لبعض المبيدات الحشرية فى مكافحة حشرة بسليد الزيتون Euphyllura straminea

(Homoptera: Psylloidea: Aphalaridae)

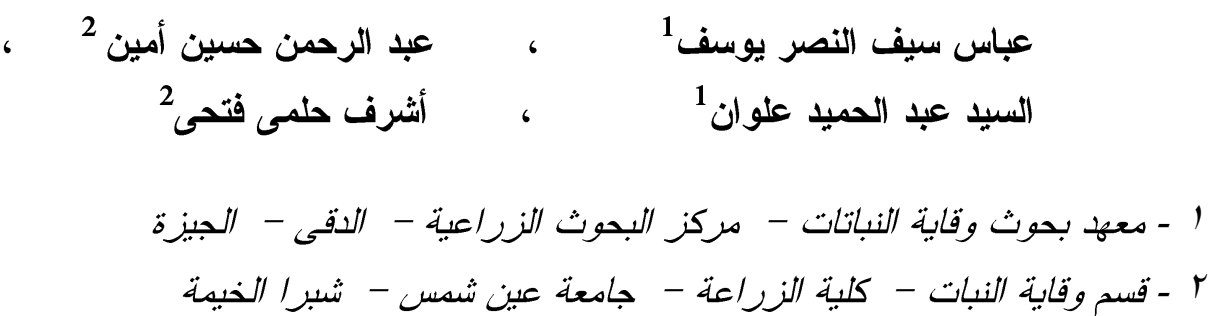

اجريت تجربة حقلية فى احدى مزارع الزيتون بناحية سر ابيوم - محافظة الاسماعيلية

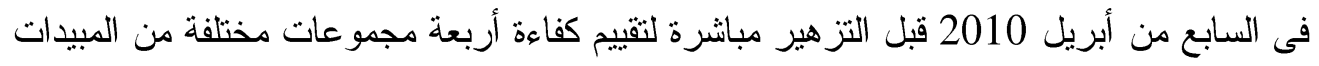
تضم ستة مبيدات حشرية لهكافحة حشرة بسيلد الزيتون Euphyllura straminea على أنثجار الزيتون بغرض حماية العحصول من الضرر الناتج عن الاصابة بهذه الآفة.

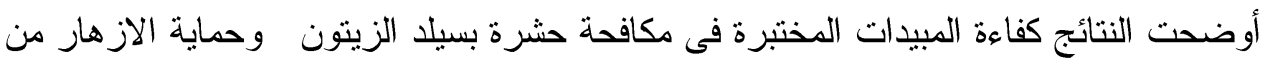

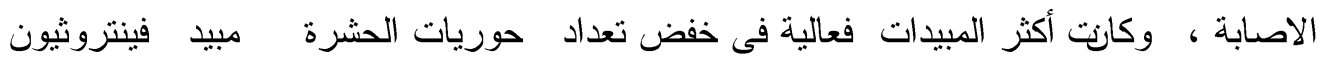

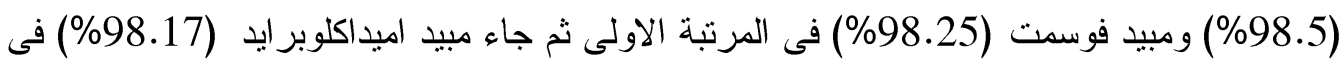

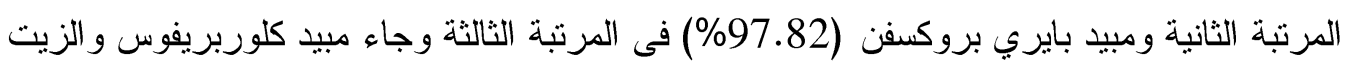

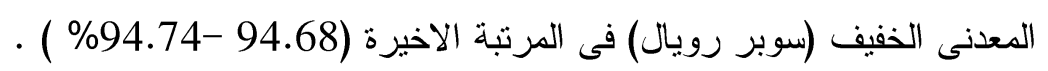

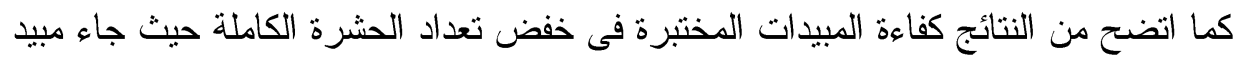

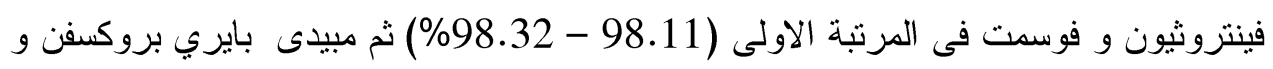

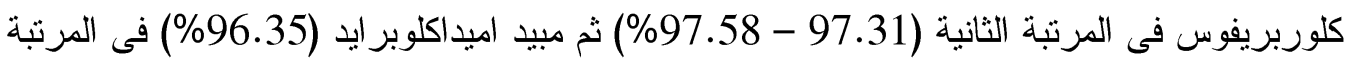
الثالثة وجاء الزيت المعنى المعدنى الذفيف (سوبر رويال) فى المرنبة الاخيرة (94.35 (94.3\%).

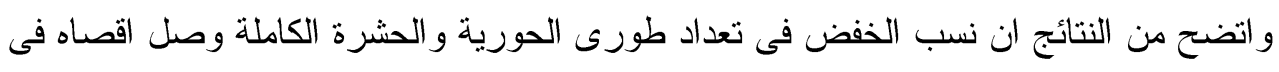

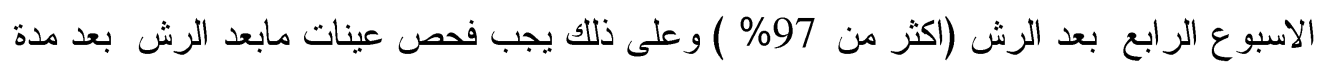
لاتقل عن 4 اسابيع من الرش للحصول على ننائج مؤكدة لفاعلية المبيدات المختبرة فى مكافحة

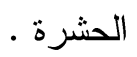

